\title{
Marriage and Family Life Satisfaction: A Literature Review
}

\author{
Ubesekera D. $\mathrm{M}^{1}$ and Jiaojiang Luo ${ }^{2}$ \\ ${ }^{1}$ Department of Sociology, Wuhan University, China, \\ ubesekaradi@yahoo.com
}

${ }^{2}$ The Institute of Social Development Studies, Department of Sociology, Wuhan University, China, jjluowhu@163.com

\begin{abstract}
This paper reviews the knowledge contributions of previous studies in the area of marriages and family life. The endeavor was to examine the extent of the knowledge contributions on this study area and to highlight possible research direction in line with the marriage and family life satisfaction. The review was done chronologically based on empirical and critical reviews of marriage patterns and family life. The review of empirical studies of marriage patterns and family life studies was done in two aspects: studies in Sri Lankan context and foreign context. According to the review it seemed that there is a research gap in the area of studying marriage patterns and their effects on family life satisfaction. In Sri Lankan context no any study could be found, on marriage and its effects on family life satisfaction. Because of this rationale, the review considered marriage as a major study phenomenon, which has a significant influence on the family life satisfaction and endeavored to provide a base for an empirical study on marriage and family life satisfaction in Sri Lankan context.
\end{abstract}

Keywords: Marriage patterns, Family life satisfaction, Marital Quality, Cohabitation

\section{Introduction}

"Marriage is one of the most intense human relationships. The quality of this relationship is continually redefined by spouses and is potentially crucial to their overall experience of family life" (Pimentel, 2000). The universality of marriage does not mean that everybody in every society gets married. It means only that most people in every society get married at least once in their life time. Marriage and family, the two social institutions with biological foundation, are complementary to each other. Both have a long standing history of their own. Marriage is one of the universal social institutions. It is established by the human society to control and regulate the sex life of human being. Marriage merely means a socially approved sexual and economic union between a woman and a man. On the other hand, marriage is the legal union of male and female. When one reaches marriageable age, he or she subconsciously or consciously enters to the spousal supply and demand system in which comparison, selection and marriage occur. It is 
closely connected with the institution of family. Rao has extracted from Gillin and Gillin as "Marriage is a socially approved way of establishing a family of procreation"; As Westermarck has remarked, "Marriage is rooted in the family rather than the family in the marriage" (Rao, 2002). When we say that marriage is universal, we do not mean that marriage and family customs are the same in all societies. On the contrary, there is much variation from society to society in how one marries, whom one marries, and how many persons one marries. The universal culture about marriage is that no society permits people to marry parents, brothers, or sisters. The family often includes more individuals than parents and their immature offspring; it may include two or more related married couples and their children. Marriage is an institution of society which can have very different cultures. Its purposes, functions and forms may differ from society to society, but it is present everywhere as an institution (Rao, 2002).

In Sri Lankan context, the marriage patterns and family life is an ongoing discussion since it has an influence on socio cultural system. There are some studies (Karunanayeke, 2000; Peris, 1964; Leach, 1967; Yalman, 1967; Wijesekara, 1980) on the present study concerns. But there is a gap on studying how marriage patterns influences on family life satisfaction.

This review considers the empirical and reviews of previous marriage patterns and family life satisfaction studies in order to identify the knowledge gap in the study area. Accordingly, empirical studies are reviewed in two contexts: Sri Lankan and Foreign.

\section{Marriage Patterns and Family Life: Literature Review}

The review of empirical studies on marriage patterns and family life studies is done in two aspects: studies in foreign contexts and Sri Lankan contexts, since it enables to identify the gaps in the study area in Sri Lanka.

\section{Marriage and Family Studies in Foreign Context}

\section{Marriage Form and Family}

Murayama (2001) investigated regional diversity of marriage behavior, especially the age at marriage and its relationship to historical change in regionalism in pre-industrial Germany and Japan. The results show that, in pre-industrial Japan, regional differences in inheritance customs determined the regional diversity of marriage patterns. The age at marriage in preindustrial Germany also showed a regional diversity, but compared to Japan, it was standardized within the European marriage pattern. Murayama (2001) conclude that "there were two different patterns standardization in marriage 
behavior in Germany, one being the historical consequence of official institutionalization and the other occurring as a process on a macroeconomic level and resulting in a concentration of age at marriage around a mean age".

South (2001) examined whether the effects of parental socioeconomic resources and childhood family structure on the timing of first marriage vary both historically and over the young adult life course in United States. Longitudinal data from the panel study of income dynamics for a sample of 6570 women and men observed between 1969 and 1993 are used to examine historical changes and life-course variation in the effects of family background characteristics on the timing of first marriage. Drawing on cultural theories of individuation and the life course approach, this study develops hypotheses for why the impact of these family background characteristics may have weakened over historical time and also weaken as young adults grow older. The study has emerged three main conclusions. First, the frequently observed delaying effects of family income and parental education on the timing of first marriage appear to have decayed significantly over the 19691993 period. These attenuated effects of family resources are broadly consistent with recent theoretical claims that, over time, individual demographic behavior has become less responsive to group pressures and normative expectations. Second, consistent with hypotheses drawn from life course theory, the effect of family resources on the transition to first marriage also dissipates as adolescents and young adults' age. Third, the analysis provides a possible clue for the racial divergence in Black and White marriage rates during the postwar period. The results suggest that the grooving racial discrepancy in first marriage timing is largely -and perhaps entirely-attributable to the declining effects of family resources on marital timing.

Li et al.,(2003) studied Marriage form and family division in three villages in rural China. This paper presents a study of children's marriage form and other characteristics on whether married couples in three villages in China establish a family separate from the joint family of their natal kin. The data used in this paper come from a sample survey of 'Marriage and old-age support' in Songzi county, Hubei province, conducted by the population research institute of Xi'an Jianthan plain in south-west Hubei on the southern side of the Yangtze river. The results reveal that, for children with a brother, sons in virilocal marriages are more likely than daughters in uxorilocal marriages to establish a family separate from that of their parents and do so earlier than these daughters. However, among children without a brother, sons and daughters do not differ significantly in whether or when they divide off from their extended family and set up a new family. The majority of family division occurs in the first 5 years after marriage for sons and daughters. Number of siblings and other characteristics also affect the likelihood of 
family division. They discuss demographic, socio-economic, and cultural causes underlying this phenomenon as well as its social implications.

\section{Marital Interaction}

Riley (1994) examined interwoven lives: parents, marriage, and Guanxi in China. This study examined the changes in the role of parents in marriage decisions in China using two data sets, the In-depth fertility survey, phase II, and data collected by the author in 1986-1987. The result showed that the number of arranged marriages, in which parents have absolute control, has decreased but in most marriages parents continue to have an influence on the decisions made parental involvement in all aspects of young people's lives is welcomed by both parents and children. Thus it showed that Guanxi provides an explanation for continuing strong kin ties. Moreover in China people rely heavily on the use of interpersonal ties (Guanxi) to acquire scarce goods and services and children often rely on parents Guanxi for help in achieving school or career goals. Riley concluded that "marriage decisions thus made in a context that supports continuing influence of parents in the lives of adult children" (Riley, 1994).

Gotman and Notarius (2000) review the advances made in the decade of the 90 s in observing marital interaction. Accordingly they have focused on the areas like study of power, the exploration of marital interaction as a proximal determinant of individual well being and distress and the study of interrelationships among interactional behavior, perception and psychology.

\section{Marriage and Cohabitation}

Axinn and Thoraton (1992) examined the relationship between cohabitation and divorce. They develop hypotheses predicting that premarital cohabitation is selective of those who are prone to divorce as well as hypotheses predicting that the experience of premarital cohabitation produces attitudes and values which increase the probability of divorce. They used data from a 23-year, seven wave study of mothers and their children. This figure represents complete information from 867 families. The results are consistent with hypotheses suggesting that cohabitation is selective of men and women who are less committed to marriage and more approving of divorce. The results also are consistent with the conclusion that cohabiting experiences significantly increase young people's acceptance of divorce.

Schoen and Weinik (1993) examined Partner Choice in Marriages and Cohabitations. Patterns of partner choice can illuminate the relationship between cohabitation and marriage. If cohabitations are "informal Marriage," partner choice in cohabitations should resemble partner choice in marriages. 
However If cohabitation is a distinct relationship, a "looser bond," then partner choice in cohabitations should give more emphasis to short-term and achieved characteristics (such as education) and less emphasis to longterm and ascribed characteristics (such as age, religion, and race). The data used in this study from the 1987-88 National Survey of Families and Households (NSFH) in United States. The (NSFH) is a national probability sample of 13,017 individuals aged 19 and over. The result strongly supportive, and show that compared to marriages, cohabiting couples are more homogamous with respect to education, are less homogamous with respect to age and religion, and show less educational hypergamy. They also point to the need for more research on how partner characteristics influence whether a cohabitation dissolves or leads to marriage.

\section{Changes of Family and Marriage}

Scanzoni (1968) examined a social system analysis of dissolved and existing Marriages. Perceptions and evaluations of the occupation; impact of "community" factors such as social background, educational level, significant others; conflict levels and their resolution; and ideologies surrounding marriage. A sample of existing marriages is compared with a sample dissolved marriages over economic, community, authority, and ideological type variables and lesser conflict and greater compromise than dissolved marriages. There was similarity between the two groups in terms of ideological factors. The study is exploratory in nature, and its conclusions are to be considered hypotheses for further research.

McCarthy (1978) studied a comparison of the probability of the dissolution of first and second marriages. This paper applies the techniques of multiple decrement life tables to marriage histories collected as part the 1973 National Survey of Family Growth in United States, in an attempt to examine differences in pattern and level of marriage dissolution by marriage order. The paper considers the process of marriage dissolution in two stagesmarriage to separation and separation to divorce, in addition to considering the composite of these two, marriages to divorce. Second marriages are more likely to remain intact only for blacks. For all subgroups of whites, second marriages are either as likely or more likely to dissolve than first marriages. For both first and second marriages, blacks are considerably less likely to obtain a divorce after separate.

Sylvia and Field (1988) present a dynamic model that encompasses the inevitable changes found in long-term marriages and makes it possible to derive patterns of relationship over time. The proposed taxonomy describes the trajectories of marriages of half century or more. Six types of very longterm marriages are specified: stable/ negative, curvilinear, continuous decline, 
and continuous increase. The sample for this study comes from the longitudinal Berkeley Older generation Study, Which yields case records of 17 marriages that have lasted for 50 to 69 years. Nearly three-quarters of the marriages show either the curvilinear or the stable/positive patterns. No continuous decline was observed. They have suggested a taxonomy of longduration marriages and have illustrated it with example from their set of 17 . In all of these marriages, there were both shared and separate interests, and in all marriages there was commitment to the marriage and acceptance of each other, however grudging the latter might be for the stable/ negatives. The stable/ neutral couples, while not reflective about the marriages, also exhibited respect and tolerance for each other. As for the stable/ positive and curvilinear couples, in addition to acceptance, commitment, tolerance, and respect, in old age they expressed understanding, affection, and love, and they were non-critical of their mates and their marriages.

Wong (1989) studied intermarriage among the Chinese in the United States in 1980. The analyses of the patterns and influence of various factors in intermarriage among the Chinese in the United States relies on the 1980 U.S. census public. The results show that, a major change in the marriage pattern among the Chinese in the United States has been occurring during the past 50 years. In the 1930s Chinese marriages were basically endogamous. Currently, however, over 30\% of Chinese marriages are intermarriages. Interestingly, the most common pattern of type of intermarriage among the Chinese in the United States was not interethnic marriages involving other Asian minorities, but interracial marriages involving whites. Moreover, Chinese females were more involved in inter marriages than Chinese male. Patterns of Chinese intermarriage are discussed. The effects of general status, residence, socioeconomic status, and acculturation on Chinese intermarriage were examined.

Xiaohe and Whyte (1990) examined the transition from arranged to freechoice marriages in People's Republic of China. They used data from a probability sample of 586 ever married women in Chegdu and Sichuan provinces in China. Retrospective data on mate- choice experience reveal that the role of parents has declined sharply, while young people more and more dominate the process of spouse selection. However, the transition toward free mate choice appears to have made little further headway in recent years, and there is still little sign of a "dating culture" emerging. Multiple regression analyses indicated that wives in Chengdu love matches are more satisfied with their marital relationships than their counterparts in arranged marriages, regardless of the length of the marriage and that this difference cannot be attributed to the influence of other background factors that diffeentiate these two types of women. 


\section{Marital Quality}

White and Booth (1985) examined the quality and stability of remarriages: The role of stepchildren. This paper separates the effects of remarriages and presence of stepchildren on the stability and satisfaction of second marriages. Using a nationwide probability sample of 1,673 married individuals interviewed in 1980 and again in 1983, they show that the higher divorce rate among remarriages is limited to the most complex form of remarriage: where both spouses have been previously married and there are stepchildren in the household. Although remarriages, as marriages, can be just as happy as first marriages, respondents with stepchildren report significantly less satisfaction with their family life than respondents with biological children. In addition to breaking up their families through divorce, stepfamilies are shown to move teenagers out of the home and empty the nest faster than biological families. They conclude that the presence of stepchildren is a destabilization influence within remarriages and a major contributor to the somewhat greater rate of divorce.

Glenn (1990) reviewed the quantitative research on marital quality in the 1980s. Glenn has explained that most of the quantitative research on marital quality in the 1980s dealt with issues emphasized in earlier research, but on the average the 1980s studies were methodologically superior to the earlier ones. The review showed that debate and discussion during the decade led to some decline in conceptual confusion, and while the research produced only a modest increment in understanding of the causes and consequences of marital success, it laid the foundation for greater in the years to come. As the decade ended, far too many of the quantitative studies of marital quality were still being conducted with small convenience samples, and many researchers seemed still not to recognize that little can be learned about the bases of marital success from cross-sectional studies of intact marriages. Many important questions about marital quality were not addressed in the 1980s or were the subject of very little research. For instance, no data were published from systematic studies of change in the overall level of marital quality or in duration specific rates of marital success in the United States. On the positive side, several developments laid the foundation for greater progress in the 1990s than that which occurred in the 1980s. For instance, a few longitudinal studies of married couples were started and are continuing, much intelligent discussion of conceptual and measurement issues dispelled some of the earlier confusion, and a change began that must take place before much understanding of the bases of marital success can be gained, namely, a shift from studies of marital quality at one point into time to research in which marital quality and stability (divorce or non divorce) are both taken into account. Such a change requires longitudinal data or retrospective data 
gathered from previously married as well as currently married persons, and it requires new data collection efforts as well as new strategies of analysis.

Country undergoing rapid economic and social change can illuminate a number of theoretical debates within marriage and family theory and accordingly Pimentel (2000) examined the existing marriage quality literature to a non-Western setting-the People's Republic of china. The population sampled was ever- married women 20-54 years of age (and their husbands), based on stratified two-stage area sampling with probability proportional size. This study applies such research to a large, representative sample of couples from urban China using a multidimensional measure of marriage quality. Accordingly has focused on characteristics unique to Chinese families-the importance of parental approval of mates and the importance of marriage type-continue to exert a strong influence on the pattern of marriage quality. The result showed that Chinese marriages are not cookie-cutter versions of western ones. Trough the marital relationship has assumed great importance in urban China; parents continue to play an influential role in determining marital happiness. Not only their approval of the marriage strongly linked to its quality,but it is also tide to the establishment of a sizable proportion of marriages, as choice of mate is still a joint effort for many Chinese families. These marriages retain a unique pattern of marital closeness, particularly with regard to the role of children within the family.

\section{Attitudes toward Family and Marriage}

Martin and Martin (1984) studied selected attitudes toward marriage and family life among college students. This study discusses the results of an extensive research study that analyzed that attitude of college students in several universities in United States: 5,237 students in four universities from the states of Arkansas, Louisiana, Oklahoma and Texas. Ten attitude areas are identified and outlined including cohabitation, premarital sexual relations, marriage and divorce, child rearing, division of labor, marital and extramarital sexual relations, social needs, communication, parental relationships and counseling services. In answering attitude statements, respondents were instructed to rate each of the attitudes on a one to five point Likert type scale ranging from strongly agree to strongly disagree. Implications for premarital counseling and future research are discussed.

Weigel and Weigel (1990) examined the role of stress and resources in family satisfaction for two-generation farm families. Data were collected from a sample of 481 adults in 1985 in Iowa. Two-generation farm families were defined as an older generation, consisting of fathers and mothers actively involved in the operation or management of the farm together with the 
younger generation, consisting of sons and daughters-in law. Regression models are developed to explore predictors of family satisfaction. The models highlight the central role of family stress, unity, and power in the perception of family satisfaction; however, the role these variables played differed for each generation. Several implications for educators and clinicians are discussed.

Goldscheider and Goldscheider (1992) studied Gender roles, marriage, and residential independence in United States. This paper examines the effects of gender role attitudes on leaving home for marriage and for unmarried independence among young men and women in the United States in 1980s. The research reported here draws on data collected between 182 and 1986 from about 30, 000 members of the high school class of 1982. They explained that high levels of premarital residential independence both expected and achieved, showing that young adults are increasingly fashioning a period in which family roles and obligations are not part of their daily lives and the gender revolution is clearly having a strong impact on these young adults' lives, with those having more egalitarian attitudes toward family and women's roles expecting and experiencing very different lives early in adulthood. In particular, they are more likely both to expect to defer marriage and actually to do so than young adults with more gender-differentiated attitudes.

\section{Methods of Studying Family and Marriage}

Miller et al., (1982) reviewed on methods of studying marriages and families. Advances in methodological approaches and tools are reviewed, emphasizing design, measurement, and analytic developments that have been most important to marriage and family research. Several emergent issues are highlighted because they seem especially likely to influence the future of research in this field. These issues include assessing the fit between empirical methods and theories, operationalizing group properties, increasing the use of secondary analysis of existing data, and the role of ethics and values in marriage and family research.

Kitson et al., (1982) examined sampling issues that should be better addressed in conducting family studies. The focus is on systematic sampling biases that cannot be handled as adequately using statistical techniques as can random sources of error. The topics include the use of probability and non-probability techniques for drawing samples, their advantages and disadvantages, and examples of the type of samples that can be drawn from public records on issues involving marriage and the family. Sampling biases produced by inadequate coverage of the sample selected also are discussed. Common problems faced in conducting and reporting upon research are illustrated through a review of divorce studies including the differences in 
coverage obtained using response and refusal rates. Suggestions are offered regarding ways to produce a more standard description of sampling issues so that researchers and users of research have cumulative body of knowledge on samples used in family research. Other methodological advances made in family studies are only as good as the foundation on which they are basedgood, well-described sampling techniques.

Surra (1990) reviewed major advances in research and theory on mate selection in the 1980s. Literature relevant to four levels of causal analysis was considered: societal trends and influences on the trends, social networks and premarital relationships, the behavioral features of relationships, and individual attributions for relationships development. Research that describes and explains relationships development also is reviewed, and four models of development are reviewed. Throughout the review, two themes appeared: developmental change and theory testing, and on the basis of conclusions evident in the review, prospects for future research are forecasted. With changes in marital patterns, mate selection in its broadest sense becomes more relevant to more people. As a result, its importance as a research topic will intensify over the next decade.

Coontz (2000) reviewed historical perspectives on family studies. This paper explored the relationships of historical research to contemporary family studies. He has explained that most of historical research confirms sociologic and ethnographic findings on the diversity of family forms, for example, it also reveals that all families are not created equal. The advantage of any particular type of family at any particular time is constructed out of contingent and historically variable social relationships. Historical research allows researchers to deepen their analysis of family diversity and family change by challenging widespread assumptions about what is and what is not truly new in family life. Such research complicates generalizations about the impact of family change and raises several methodological cautions about what can be compared and controlled for in analyzing family variations and outcomes.

According to the knowledge contribution from previous empirical studies on marriage and family in foreign context, the review discloses that, there are many different studies on marriage and family activities. Nevertheless, in foreign context no any study could be found on marriage patterns and their effects on family life satisfaction.

\section{Marriage and Family Studies in Sri Lankan Context}

Among the socio cultural issues in Sri Lankan context divorces, suicide, child abuse, prostitution, separation, and sexual transmission diseases etc., are under major concerns. These issues are related to individual's family life. 
Marriage is one of the factors affecting to one's family life. Family life dissatisfaction leads to such social issues. The paper endeavors to provide to insights for future research studies in Sri Lankan contexts through reviewing the studies related to marriage patterns and family life.

Munck (1996) studied love and marriage in a Sri Lankan Muslim community-toward a reevaluation of Dravidian marriage practices. He argued that structural and transactional models of Dravidian marriage practices cannot adequately account for the variation in mate selection in situations of arranged marriage practices exhibited among the Sri Lankan Muslims of Kutali. It showed that the inadequacy of these models is an out come of three interrelated problems: (l) The assumption of a normative model for marriage; (2) a dichotomous conceptualization of marriage practices that divides them into love and arranged marriage categories; and (3) the absence of romantic love as a valid motivation for mate selection. This study showed that villagers use a polythetic model for marriage in which core symbols of marriage category types are manipulated to serve as figure or ground depending on situational contingencies. Second, love can be accommodated to an arranged marriage model. In addition, Malhotra and Tsui (1996) have provided empirical evidence to the critique of modernization theory, which continues to underpin much social research on non-western societies despite the frequent and open challenges to its legitimacy and ability in predicting family change. They used longitudinal data, focus group information and event history models to examine the timing of marriage for a cohort of young women in Sri Lanka. They argued that despite the infusion of modern ideational factors, family organization, interests, and cultural prescriptions have a substantial role to play in determining when young Sri Lankan women enter marriage. The results supported that contention that the process of social change does not involve a linear shift from a consistent, packaged set of traditional conditions to modern ones, but rather a more complex interactions and coexistence of these two sets of values. The results showed that family and cultural factors continue to be important in determining marriage timing for the present generation of young women in Sri Lanka. To undertake research to ascertain whether nuptiality patterns are changing, as such changes may have a tremendous impact on fertility in Sri Lanka. Fernando (1975) studied on the changing nuptiality pattern in Sri Lanka between 1901 and 1971. The study utilizes data from the published reports of the censuses of 1901, 1911, 1921, 1946, 1953 and 1963. The data for 1971 are confined to the ten percent sample tabulations from the 1971 census of population that was presently available. The published annual reports of the Registrar General of Sri Lanka on vital Statistics for the period 1901-66 are also utilized and are supplemented with unpublished data from his Department for the 1967 to 1971 . The results showed that the reductions in 
the proportions marrying at the prime childbearing years 20-29 are of considerable significance for fertility reduction. In addition, the transition in nuptiality during 1901-71 has been dominated by postponement of marriage by women and by a remarkably stable level of spinsterhood at four to five per cent at all censuses in and after 1946. Thus it showed that in 1901 spinsterhood was at a higher level, ten per cent.

Caldwell et al., (1989) studied, is marriage delay a multiphasic response to pressures for fertility decline? They used both survey and anthropological methods were employed to study 10, 964 persons living in 1,974 households in seven rural and urban locations of southwest Sri Lanka. Marriage histories were compiled, and special studies were undertaken for three groups: persons nearing and reaching the age at marriage; bachelors and spinsters of an age when people were normally married; and women over 60 years of age. It was discovered that the rising age of marriage for females had not been an attempt to limit fertility. The low traditional age at marriage had been enforced by parents through arranged marriages so as to forestall unsuitable marriages, especially those across caste. With the transitions to a society dominated by nonagricultural employment and high levels of education, these aims became less important and parental pressures slackened. There appears to be evidence that young females themselves felt no great urgency about immediate post pubescent marriages and with the reduction of parental pressure, female age at marriage spontaneously rose. "Love" or non-arranged marriages are now in the majority and offer both advantages and disadvantages to the young and their parents alike. In both types of marriage further delays result from increased unemployment because of a consensus that the bridegroom must have satisfactory employment and increasing agreement that the bride also should have been employed.

According to the previous empirical studies on marriage and family in Sri Lankan context, it reveals that, there are some few studies related to the marriage and family background phenomena such as, love and marriage in a Sri Lankan Muslim community, modernization theory and family changes, nuptiality pattern, marriage delay and fertility decline. Marriage patterns and family life are interrelated social phenomena, nevertheless, couldn't found any study attempted to this area in Sri Lankan context.

\section{Summary of the Literature Review}

Figure 1 demonstrates the summary of whole literature review on studies of marriage and family. Accordingly, whole literature reviews are divided into two categories as Sri Lankan studies and foreign studies. Meanwhile aforesaid figure further shows that the basic scholarly works found in the field of marriage and family life background i.e. marriage form and family, marital 
interaction, changes of marriage and family, marital quality, attitudes on marriage and family, love and marriage, nuptiality patterns and fertility and marriage delay and fertility. However, there is no any study found on marriage patterns and family life satisfaction in Sri Lanka and the other foreign countries as well. In this regard this review may show another research direction in the field of marriage and family studies.

\begin{tabular}{|c|c|}
\hline & Marriage and Family Studies \\
\hline Sri Lankan studies & Foreign studies \\
\hline $\begin{array}{l}\text { Modernization theory and } \\
\text { family change } \\
\text { (Malhotra and Tsui, 1996). }\end{array}$ & Dissolved and existing Marriages (Scanzoni, 1968). \\
\hline $\begin{array}{l}\text { Love and marriage (Munck, } \\
\text { 1996). }\end{array}$ & $\begin{array}{l}\text { Probability of the dissolution of first and second marriages } \\
\text { (McCarthy, 1978). }\end{array}$ \\
\hline $\begin{array}{l}\text { Changing nuptiality pattern } \\
\text { and fertility } \\
\text { (Dallas and Fernando, 1975). }\end{array}$ & Methods of studying marriages and families (Miller, et al.1982). \\
\hline \multirow{20}{*}{$\begin{array}{l}\text { Marriage delay and fertility } \\
\text { decline (Caldwell et al., } \\
\text { 1989). }\end{array}$} & Sampling issues and family studies (Kitson et al.,1982). \\
\hline & Marriage attitudes and family life (Martin and Martin, 1984). \\
\hline & The quality and stability of remarriages (White and Booth, 1985) \\
\hline & Marriage continuity or change (Sylvia and Field, 1988). \\
\hline & $\begin{array}{l}\text { Intermarriage among the Chinese in the United States (Wong, } \\
\text { 1989). }\end{array}$ \\
\hline & $\begin{array}{l}\text { The quantitative research on marital quality in the 1980s(Glenn, } \\
\text { 1990). }\end{array}$ \\
\hline & Research and theory on mate selection in the 1980s (Surra,1990). \\
\hline & $\begin{array}{l}\text { Stress and resources in family satisfaction (Weigel and Weigel } \\
\text {,1990). }\end{array}$ \\
\hline & $\begin{array}{l}\text { Marriage transition, from arranged to free-choice marriages } \\
\text { (Xiaohe and Whyte, 1990). }\end{array}$ \\
\hline & Cohabitation and divorce (Axinn and Thoraton, 1992). \\
\hline & $\begin{array}{l}\text { Gender roles, marriage, and residential independence } \\
\text { (Goldscheider and Goldscheider, 1992). }\end{array}$ \\
\hline & $\begin{array}{l}\text { Partner Choice in Marriages and Cohabitations(Schoen and } \\
\text { Weinik, 1993). }\end{array}$ \\
\hline & Interwoven lives: parents, marriage, and Guanxi (Riley, 1994). \\
\hline & Historical perspectives on family studies (Coontz, 2000). \\
\hline & Marital interaction (Gotman and Notarius, 2000). \\
\hline & Existing marriage quality (Pimentel, 2000). \\
\hline & $\begin{array}{l}\text { Regional diversity of marriage behavior (Murayama, } \\
\text { 2001). }\end{array}$ \\
\hline & $\begin{array}{l}\text { Parental socioeconomic resources and childhood family structure } \\
\text { on the timing of first marriage (South, 2001). }\end{array}$ \\
\hline & Marriage form and family division (Li et al., 2003). \\
\hline & $\begin{array}{l}\text { Marriage form and fertility (Li and Feldmen, } \\
\text { 2004). }\end{array}$ \\
\hline
\end{tabular}

Figure 1 : Marrage and Family Studies in Sri Lankan Context and Foreign Context 


\section{Discussion and Conclusion}

Literature review evidenced that there are many studies on marriage and family. However, it seemed that there is a research gap in the area of studying marriage patterns and their effects on family life satisfaction. In Sri Lankan context no any study could be found on marriage patterns and their effects on family life satisfaction. Because of this rationale, the review considers marriage patterns as a major study phenomenon, which has a significant influence on the family life satisfaction.

Figure 2 illustrates that how marriage patterns influences family life satisfaction and relationships between marriage patterns and family life satisfaction. Thus, it shows that marriage and family are social institutions while marriage patterns and family life satisfaction as functions. Marriage and family are interdependent institutions in the society. Moreover it shows that to ensure formal functioning of a family it is required to establish family life satisfaction.

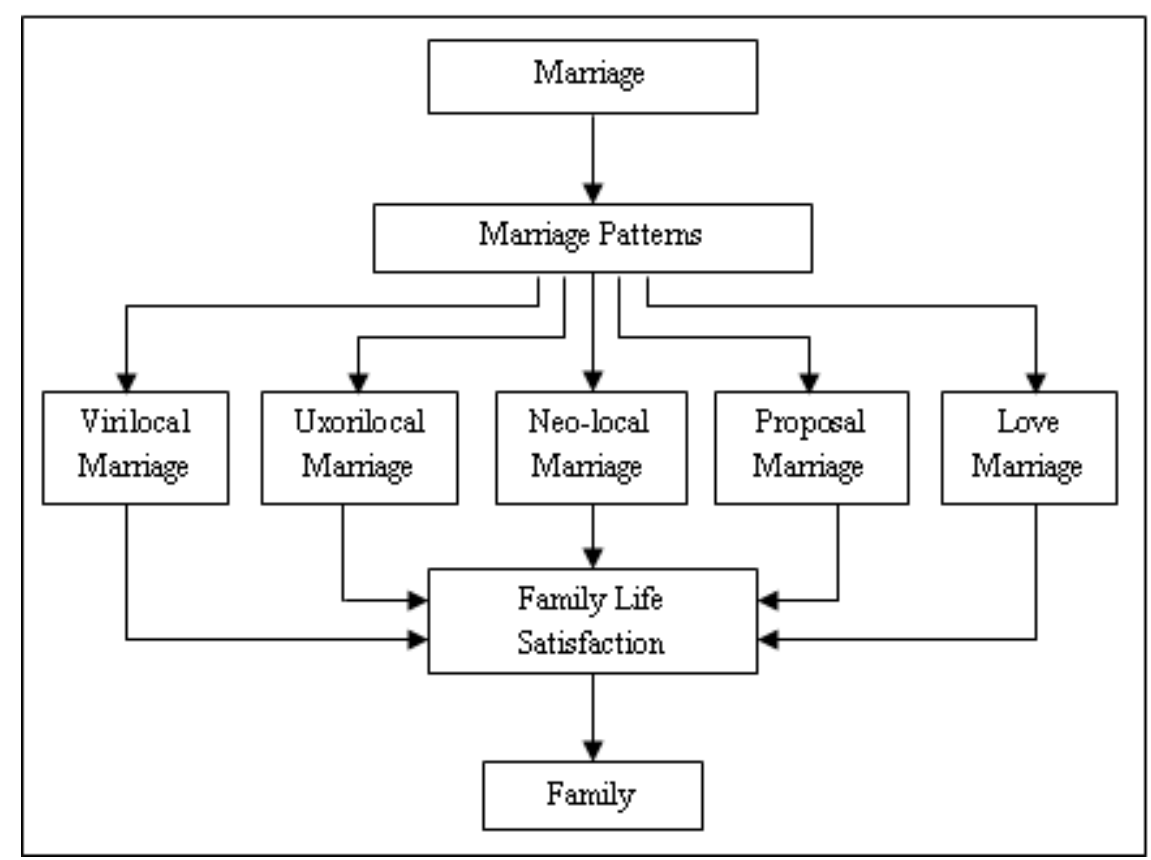

Figure 2: Marriage Patterns and their affect on Family life Satisfaction

Family is one major institution in the society that has an effect on the better functioning of the social system. In addition, for the better functioning of a family, the family must be a formally constructed. Higher level of family life satisfaction is required to establish, secure and enhance the formal functioning of a family. Functionalists view the family as an institution with values, norms, and activities meant to provide stability for the larger society. 
Such stability is dependent on families serving various functions for society (Knox and Schacht, 1997). There are many factors influencing the satisfaction of a family life i.e. marriage, economic condition, cultural, religious factors etc. Among these, marriage patterns of the major actors, which influence on the family life satisfaction i.e. love marriage, proposal marriage patrilocal, metrilocal, neo-local etc. On the other hand marriage relationship creates the family and all the other factors which influences on the satisfaction of the family life are related to marriage.

In that sense, this article is significant to highlight the requirements of empirical studies on how marriage patterns effects in family life satisfaction, in Sri Lankan context and others and the review elaborated the previous knowledge contribution and through that it has attempted to provide an insight on future research directions.

\section{References:}

Axinn, W.G. and Thoraton, A. (1992) The relationship between cohabitation and divorce: Selectivity or causal influence?. Demography, v.29(3), pp. 357-374.

Caldwell, J., Gajanayake, I. and Caldwell, B. (1989) Is marriage delay a multiphasic response to pressures for fertility decline? The case of Sri Lanka. Journal of Marriage and the Family, v. 5l(2), pp. 337-35l.

Coontz, S. (2000) Historical perspectives on family studies. Journal of marriage and family, v. 62(2), pp. 283-297.

Fernando, D.F.S. (1975) Changing nuptiality patterns in Sri Lanka. Population Studies, v. 29(2), pp. 179-190.

Glenn, N. D. (1990) Quantitative research on marital quality in the 1980s: A Critical Review. Journal of Marriage and the Family, v. 52(4), pp. 818831.

Goldscheider, F.K. and Goldscheider, C. (1992) Gender roles, marriage and residential independence. Sociological Forum, v. 7(4), pp. 679-696.

Gotman, J. M. and Notarius, C.I. (2000) Decade review: Observing marital interaction. Journal of Marriage and the Family, v. 62(4), pp. 927-947.

Karunanayake, N. (2000) The Chinging Patterns of Marriage in Sri Lanka. Nugegoda: The institute for professional Development.

Kitson, G.C., Sussman, M.B., Williams, G.K., Zeehandelaar, R.B., Shickmanter, B. K. and Steinberger, J. L. (1982) Sampling issues in family research. Journal of Marriage and the Family, v. 44(4), pp. 965981. 
Knox, D. and Schacht, C. (1997) Choice in Relationships: An Introduction to Marriage and the family. USA: Wadsworth.

Leach, E. R. (1967) Pul Eliya. London: Cambridge University press.

Li, S., Feldman, M.W. and Jin, X. (2003) Marriage form and family division in three villages in rural China. Population Studies, v. 57(1), pp. 95-108.

Malhotra, A. and Tsui, A.O. (1996) Marriage timing in Sri Lanka: The role of modern norms and ideas. Journal of Marriage and Family, v. 58(2), pp. 476-490.

Martin, D. and Martin, M. (1984) Selected attitudes toward marriage and family life among college students. Family relations, v. 33(2), pp. 293300.

McCarthy, J. (1978) A comparison of the probability of the dissolution of first and second marriages. Demography, v. 15(3), pp. 345-359.

Miller, B. C., Rollins, B. C. and Thomas, D. L. (1982) On methods of studying marriages and families. Journal of Marriage and the Family, v. 44(4), pp. 851-873.

Munck, V.C.D. (1996) Love and marriage in a Sri Lankan Muslim community: Toward a reevaluation of Dravidian marriage practices. American Ethnologist, v. 23(4), pp. 669-716.

Murayama, S. (2001) Regional standardization in the age at marriage: a comparative study of pre-industrial Germany and Japan. History of the Family,v. 6, pp. 303-324.

Pimentel, E. E. (2000) Just How Do I love thee? Marital relations in urban China. Journal of Marriage and the Family,v. 62(1), pp. 32-47.

Peris, R. (1964) Sinhalese Social Organization. Maharagama: Saman Publisher company.

Rao, C.N.S. (2002) Sociology: primary principles of sociology with an introduction to social thought. New Delhi: S.Chand.

Riley, N. E. (1994) Interwoven lives: Parent, marriage, and Guanxi in China. Journal of Marriage and the Family,v. 56(4), pp. 791-803.

Scanzoni, J. (1968) A social system analysis of dissolved and existing Marriages. Journal of Marriage and the Family, v. 30(3), pp. 452-461.

Schoen, R. and Weinik, R. M. (1993) Partner choice in marriages and cohabitations. Journal of Marriage and the Family, v. 55 (2), pp. 408-414. 
South, S. J. (2001) The variable effects of family background on the timing of first marriage: United States, 1969-1993. Social Science Research, v. 30, pp. 606-626.

Surra, C.A. (1990) Research and theory on mate selection and premarital relationships in the 1980s. Journal of Marriage and the Family, v. 52(4), pp. 844-865.

Sylvia, W. and Field, D. (1988) A half century of marriage: Continuity or change?. Journal of Marriage and the Family, v. 50(3), pp. 763-774.

Weigel, D. J. and Weigel, R. R. (1990) Family satisfaction in two-generation farm families: The role of stress and resources. Family relations, v. 39(4), pp. $449-455$.

White, L.K. and Booth, A. (1985) The quality and stability of remarriages: The role of stepchildren. American Sociological Review, v. 50(5), pp. 689-698.

Wijesekara, N. (1980)The Sinhalese. Colombo: Gunasena and Ltd.Company

Wong, M.G. (1989) A look at intermarriage among the Chinese in the United States in 1980. Sociological Perspectives, v. 32(1), pp. 87-107.

Xiaohe, X. and Whyte, M.K. (1990) Love matches and arranged marriages: A Chinese replication. Journal of Marriage and the Family, v. 52(3), pp. 709-722.

Yalman, N. (1967) Under the Bo-tree. U.S.A: University of California Press. 
1 